Rafał Kania (Płock)

\title{
Prawne podstawy systemu ochrony przed pożarami w Królestwie Polskim (1815-1830)
}

\section{WPROWADZENIE}

Jednymi z największych niebezpieczeństw generowanych przez środowisko, z którym zmagali się mieszkańcy Królestwa Polskiego doby konstytucyjnej, były pożary. Zagrożenie wynikało przede wszystkim z ówczesnej technologii budownictwa. Na niskim poziomie pozostawały także metody działań prewencyjnych oraz sposoby walki z żywiołem ${ }^{1}$. Na szczególne niebezpieczeństwo pożaru narażona była zwarta zabudowa miejska².

Pożary powodowały nie tylko bezpośrednie zagrożenie utraty życia lub zdrowia ludzi. Skutkowały również negatywnymi konsekwencjami w obszarze materialnych podstaw ich niezależności. Zniszczone zabudowania przestawały dawać schronienie, a utrata inwentarza i zapasów powodowała realne niebezpieczeństwo dla podtrzymania biologicznej egzystencji. Brak narzędzi lub urządzeń służących do wykonywania pracy zarobkowej powodował również pośrednio zagrożenie dla stabilności systemu społeczno-gospodarczego.

Organizatorzy porządku wewnętrznego Królestwa Polskiego stanęli przed koniecznością wprowadzania rozwiązań systemowych, pozwalających zniwelować negatywne konsekwencje pożarów. Nie ograniczono się wyłącznie do surowego \footnotetext{
s. $53-54$.

2 Jako przykład można wskazać pożar Strykowa z 1809 r. Zob.: E. Berezowski, Rajmund Rembieliński - urbanista i budowniczy miast $w$ województwie mazowieckim w okresie Królestwa Polskiego (1815-1832) [w:] A. Barszczewska-Krupa (red.), Rajmund Rembieliński. Jego czasy i jego wspótcześni, Warszawa 1989, s. 99.
}

${ }^{1}$ S. Kieniewicz (red.), Dzieje Warszawy. Warszawa w latach 1795-1914, Warszawa 1976, 
karania sprawców podpaleń ${ }^{3}$. Na politykę bezpieczeństwa wewnętrznego władz Królestwa Polskiego w obszarze ochrony przeciwpożarowej składał się szereg innych działań. Przedmiotem artykułu jest analiza prawnych podstaw kluczowego elementu systemu ochrony przeciwpożarowej Królestwa Polskiego, za jaki należy uznać organizację Towarzystwa Ogniowego. Celem prowadzonych poszukiwań będzie próba rekonstrukcji wybranych elementów wizji polityki wewnętrznej władz państwa w latach 1815-1830.

\section{OGÓLNE ZAŁOŻENIA SYSTEMU}

Kluczowym aktem prawnym leżącym u podstaw budowy systemu ochrony przed skutkami pożarów było postanowienie namiestnika z 9 lipca $1816 \mathrm{r}$. w sprawie utworzenia Towarzystwa Ogniowego ${ }^{4}$. Zgodnie z intencjami prawodawcy system miał objąć całe Królestwo Polskie. Wprowadzenie nowych rozwiązań namiestnik Zajączek uzasadniał korzyściami, jakie mieli uzyskać właściciele nieruchomości, a pośrednio także państwo. Odwoływał się przy tym do zasady słuszności jako fundamentu nowych rozwiązań. Zgodnie bowiem z założeniami wprowadzanych regulacji właściciele mieli partycypować w kosztach systemu w stopniu nie większym niż wynikałoby to ze specyfiki chronionej nieruchomości. Celem podstawowym, zdaniem namiestnika, bardzo potrzebnej instytucji, miało być sprawne gromadzenie środków ze składek oraz udzielanie wsparcia finansowego właścicielom nieruchomości dotkniętych pożarem. Obowiązkiem Towarzystwa Ogniowego było przeciwdziałanie pobieraniu składek w nadmiernej wysokości, a także uniemożliwienie przeznaczania zgromadzonych środków na cele inne niż likwidacja skutków pożarów. Ponadto nowa organizacja miała ograniczyć koszty administracyjne ochrony. Postanowienie zostało wydane na wniosek Komisji Rządowej Spraw Wewnętrznych i Policji, po przeprowadzeniu dyskusji na posiedzeniu Rady Stanu ${ }^{5}$.

Zgodnie z intencją autorów nowym systemem objęto nieruchomości budynkowe, znajdujące się na terenie wszystkich miast Królestwa Polskiego (§ 1).

${ }^{3}$ Zob.: art. 142-151, 384-397 Kodeksu prawa karzącego w Królestwie Polskim, D.P.K.P., t. V, s. 1-292.

${ }^{4}$ Ostateczna wersja postanowienia została przyjęta na posiedzeniu Rady Stanu 8 lipca $1816 \mathrm{r}$. Rps, AGAD, I Rada Stanu Królestwa Polskiego, sygn. 271, Towarzystwo Ogniowe, s. 55.

${ }^{5}$ Postanowienie namiestnika z dnia 9 lipca 1816 r., Zaprowadzające w całym Królestwie Polskim, na miejsce dawniejszego, które się znosi, ogólne towarzystwo ogniowe, do którego bez wyjątku wszystkie miasta należą. Jego urządzenie, rozkład składek, zabezpieczenie onych, aby nie na inny przedmiot, tylko na dopomożenie pogorzelcom stawiania nowych domów na miejsce spalonych, użyte były. Niemniej trwające dotąd Towarzystwo ogniowe wsiów zachowujące, D.P.K.P., t. I, s. $421-422$. 
Zabudowania podzielono na dwie klasy (§ 2). Do pierwszej należały budynki i budowle murowane z cegły oraz wznoszone z „ziemi bitej”, kryte blachą, kamieniem lub dachówką. Drugą tworzyły wszystkie pozostałe zabudowania (§ 3). Fundusze gromadzone ze składek właścicieli nieruchomości zaliczanych do poszczególnych klas mogły zostać wykorzystane wyłącznie na wsparcie pogorzelców kategorii, do której należały zniszczone zabudowania (§ 4).

Składki dzielono na dwa rodzaje: stałe i dodatkowe (§5). W przypadku budynków murowanych składka stała wynosiła osiem groszy za każde sto złotych wartości nieruchomości. Budynki murowane kryte inaczej niż zostało to określone w §3, objęte zostały stawką dwunastu groszy od każdych stu złotych ich wartości. Właściciele pozostałych nieruchomości zabudowanych zostali zobowiązani do uiszczania szesnastu groszy (§ 6). Składką w podwójnej wysokości stawki bazowej miały zostać objęte budynki narażone na większe ryzyko pożaru, w szczególności rękodzielnie i fabryki wykorzystujące ogień w procesie produkcji lub gromadzące materiały łatwopalne (§ 8). Składka stała miała być uiszczana w dwóch półrocznych ratach począwszy od 1 stycznia 1817 r. (§ 7). System nie objął budynków i budowli, w których niebezpieczeństwo pożaru było szczególnie wysokie. Zaliczono do tej kategorii fabryki prochu, ludwisarnie, fryszerki i huty (§ 9).

Budżetowanie oraz rachunkowość Towarzystwa prowadzono w porządku rocznym. Bilans działalności miał być sporządzany na dzień 31 grudnia. W terminie do 31 marca roku następnego Dyrekcja Generalna składała sprawozdanie finansowe, obejmujące przychody i rozchody. Po stronie przychodów miał znaleźć się wykaz zebranych składek z podziałem na klasy nieruchomości oraz stan zgromadzonych środków na koniec roku. Z kolei po stronie rozchodów umieszczano informacje o wypłatach przekazanych świadczeniobiorcom, zawierające szczegółowe dane o miejscu, czasie, poszkodowanym oraz szkodzie. Ponadto dodawano informację o poniesionych kosztach administracyjnych Towarzystwa Ogniowego. Zestawienie kończyło się syntetycznym ujęciem wyniku finansowego. Towarzystwo przedkładało sprawozdanie Komisji Rządowej Spraw Wewnętrznych i Policji (KRSWiP) ${ }^{6}$. Po weryfikacji i zatwierdzeniu treść dokumentu podawano do publicznej wiadomości (§ 10).

W postanowieniu przewidziano działania na wypadek powstania straty bilansowej w roku budżetowym (§ 11). Po jej stwierdzeniu Dyrekcja Generalna Towarzystwa Ogniowego na podstawie upoważnienia KRSWiP dokonywała w kolej-

${ }^{6}$ Do zadań KRSWiP należało zabezpieczenie porządku i bezpieczeństwa publicznego, wolności osób i ich mienia. J. Bardach, M. Senkowska-Gluck (red.), Historia ustroju i prawa Polski, t. III: Od rozbiorów do uwłaszczenia, Warszawa 1981, s. 343. 
nym roku poboru składki dodatkowej ${ }^{7}$, pokrywającej deficyt. Jeśli rok zakończył się nadwyżką, składka w roku kolejnym zostawała proporcjonalnie obniżona. Rolę, jaką odgrywało sprawne funkcjonowanie finansów Towarzystwa Ogniowego potwierdza fakt, iż dokonana na mocy postanowienia królewskiego w $1820 \mathrm{r}$. konsolidacja systemu gospodarowania środkami finansowymi przez instytucje publiczne Królestwa Polskiego nie objęła kasy Towarzystwa Ogniowego ${ }^{8}$.

Głównym zadaniem Towarzystwa było udzielanie wsparcia finansowego właścicielom, których nieruchomości zostały dotknięte pożarem lub które zostały uszkodzone albo zniszczone w wyniku działań prewencyjnych lub ratunkowych podczas pożaru. Wysokość wypłacanych świadczeń miała odpowiadać rzetelnie oszacowanej wartości zniszczonych zabudowań. Wypłata z kasy głównej Dyrekcji Towarzystwa odbywała się $\mathrm{w}$ trzech równych ratach, $\mathrm{w}$ chwili rozpoczęcia odbudowy, po przeprowadzeniu połowy prac oraz po ich zakończeniu. Na czas odbudowy właściciel nieruchomości podlegał zwolnieniu od obowiązku uiszczania kolejnych składek (§ 12).

Na czele Towarzystwa Ogniowego stała Dyrekcja Generalna, utworzona przy KRSWiP (§ 13). Organ działał kolegialnie pod przewodnictwem komisarza. Jego skład oraz uposażenie miało zostać uregulowane w odrębnym postanowieniu. Opracowanie struktury wraz z instrukcją określającą funkcjonowanie Dyrekcji powierzono KRSWiP. Członkowie Dyrekcji oraz kasjer zobowiązani zostali do złożenia kaucji na okres pełnienia funkcji (§ 14). Rachunkowość Towarzystwa Ogniowego, po wstępnej weryfikacji przeprowadzonej przez urzędników ministerialnych, podlegała ocenie Izby Obrachunkowej (§ 16).

Pomimo pierwotnych planów utworzenia czterech towarzystw ogniowych", ostatecznie poprzestano na dwóch. Na mocy postanowienia z 9 lipca $1816 \mathrm{r}$. czasowo utrzymano funkcjonujące dotychczas Towarzystwo Ogniowe dla wsi. Zostały nim objęte nieruchomości w dobrach narodowych, gminnych, duchownych, ,instytutowych”. Zezwolono także na pozostanie pod egidą Towarzystwa wsiom dziedzicznym. Właściciele dóbr prywatnych mogli również do niego przystępować. Dla nieruchomości wiejskich Dyrekcja Generalna miała obowiązek utrzymywać oddzielną kasę oraz prowadziła odrębną sprawozdawczość finansową (§ 15).

${ }^{7}$ Przykładem zastosowania tego mechanizmu był Reskrypt Aleksandra I z 11 stycznia $1821 \mathrm{r}$. o poborze składki dodatkowej od 1821 r. przez 6 lat. Rps, AGAD, I Rada Stanu Królestwa Polskiego, sygn. 271 Towarzystwo Ogniowe, s. 95-99.

${ }_{8}^{8}$ Postanowienie Aleksandra I z 27 listopada (7 grudnia) 1820 r., Uchylenie od 1 stycznia 1821 r. wszelkich Kas przy różnych władzach Rządowych znajdujących się, a zwrócenie wszelkiego poboru i wypłat do Kas Skarbowych, zachowując tylko Kasy pocztowe, miejskie, wojskowe i Towarzystwa Ogniowego, D.P.K.P., t. VII, s. 105.

9 Rps, AGAD, I Rada..., s. 3. 
Towarzystwo Ogniowe powołane uchwałą Komisji Rządzącej z 4 czerwca $1807 \mathrm{r}^{10}$ miało ulec rozwiązaniu z dniem 31 grudnia 1816 r. Jego zobowiązania nie przechodziły na nowo utworzone Towarzystwo. Przy tej okazji namiestnik zobowiązywał KRSWiP do przedłożenia programu określającego zasady zaspokajania roszczeń pogorzelców z lat 1806-1816. Sprawozdanie z tych działań miało zostać podane do publicznej wiadomości (§ 17-18). Likwidacja roszczeń powstałych przed 31 grudnia 1816 r. postępowała wolno. Świadczy o tym wydane przez namiestnika 24 stycznia 1818 r. postanowienie, które określało zasady ostatecznego rozliczenia finansów Towarzystwa Ogniowego czasów Księstwa Warszawskiego. W zamyśle władz Królestwa Polskiego, miało ono kończyć zaległe sprawy odszkodowawcze ${ }^{11}$. Celu tego nie udało się jednak w pełni osiągnąć.

\section{ORGANIZACJA TOWARZYSTWA OGNIOWEGO}

Namiestnik Zajączek wydał 7 stycznia 1817 r. na wniosek KRSWiP postanowienie uzupełniające treść postanowienia z 9 lipca 1816 r. (art. 1). Na jego mocy do nowego Towarzystwa Ogniowego weszły obligatoryjnie wszystkie miasta. Utrzymano podział zabudowań na dwie klasy (§ 12). Potwierdzono 1 stycznia 1817 r. jako dzień rozpoczęcia poboru składek. Budynki i budowle dotychczas wyłączone spod ochrony zostały obligatoryjnie objęte ubezpieczeniem w ramach nowego systemu. Ponadto miał być opracowany ich kataster oraz ustalona wysokości opłat (art. 3).

Na mocy cytowanego postanowienia, 31 grudnia 1816 r. rozwiązano dotychczas istniejące Towarzystwo Ogniowe dla nieruchomości wiejskich. Na jego miejsce 1 stycznia $1817 \mathrm{r}$. powołano nową instytucję (art. 4). W przeciwieństwie do nieruchomości miejskich, właściciele dziedzicznych dóbr wiejskich mogli pozostać poza systemem. W takim przypadku, w terminie do 1 lutego 1817 r., mieli obowiązek złożenia stosownego oświadczenia Dyrekcji Generalnej. Deklaracje wniesione po tej dacie wywoływały skutek dopiero z początkiem następnego roku (art. 5). Dobra wiejskie objęte wcześniej ochroną, miały zostać uwzględnione w katastrach Towarzystwa Ogniowego dla wsi. Nieruchomości pozostające dotychczas poza systemem miały zostać objęte ochroną po zatwierdzeniu

${ }^{10}$ M. Roztworowski (oprac.), Materiaty do dziejów Komisji Rządzącej z r. 1807, Kraków 1918, t. I, s. 641-656.

${ }_{11}$ Postanowienie namiestnika z 24 stycznia 1818 r., Prawidła względem zakwitowania rachunków towarzystwa ogniowego, D.P.K.P., t. VI, s. 287. 
właściwych katastrów (art. 6). Wykonanie wydanego aktu namiestnik powierzył KRSWiP. Postanowienie zostało ogłoszone 31 marca $1817 \mathrm{r}^{12}$

Także 7 stycznia 1817 r. namiestnik wydał postanowienie określające organizację Dyrekcji Generalnej Towarzystwa Ogniowego. Określono jej skład oraz budżet. Dyrekcja liczyła dwanaście etatów. Obok kwoty przeznaczonej na wynagrodzenia, przewidziano środki na materiały biurowe. Łącznie budżet wynosił 47500 złotych. Koszty administracyjne pokrywano ze składek (art. 2).

Czynności podejmowane $\mathrm{w}$ ramach przyznanych kompetencji Dyrekcja wykonywała kolegialnie. W skład Kolegium Dyrekcji wchodził przewodniczący wraz z trzema asesorami. Trzech członków tworzyło quorum. W przypadku równości głosów przeważał głos przewodniczącego (art. 3). Członków mianował namiestnik na wniosek KRSWiP. Pozostali urzędnicy Dyrekcji byli powoływani przez KRSWiP (art. 6). Do kompetencji Dyrekcji należało przygotowanie projektu organizacji wewnętrznej, który miała zatwierdzić KRSWiP (art. 4). Przewodniczący, asesorzy oraz kasjer mieli obowiązek wniesienia kaucji w wysokości odpowiednio: 18 000, 6000 i 12000 złotych (art. 5). W zakresie powierzonych zadań Dyrekcja współpracowała z komisjami wojewódzkimi (art. 7). Postanowienie zostało ogłoszone 31 marca 1817 r. $^{13}$

\section{TOWARZYSTWO OGNIOWE MIAST}

W uzupełnieniu treści § 14 postanowienia z 9 lipca 1816 r. namiestnik wydał 28 stycznia 1817 r. postanowienie zawierające ,urządzenie i instrukcję" Towarzystwa Ogniowego dla miast, opracowane przez KRSWiP. Był to najobszerniejszy akt normatywny dotyczący zabezpieczenia przed zagrożeniem pożarowym. Liczył łącznie pięćdziesiąt artykułów, podzielonych na cztery Tytuły. Do postanowienia dołączono załączniki, zawierające wzory: sprawozdania finansowego, „tax szczegółowych” i „tax ogólnych”, katastru z podziałem na dwie klasy nieruchomości, świadectwa potwierdzenie ujęcia budynków i budowli w systemie, protokołu strat wywołanych pożarem oraz protokołu usunięcia szkód powstałych w wyniku pożaru ${ }^{14}$.

W Tytule I określono zasady przystępowania do Towarzystwa Ogniowego oraz wysokość opłat i zasady prowadzenia katastru nieruchomości. System miał

${ }_{12}$ Postanowienie namiestnika z 7 stycznia 1817 r., Ustanowienie Towarzystwa ogniowego miast i wsi, D.P.K.P., t. III, s. 52.

${ }_{13}$ Postanowienie namiestnika z 7 stycznia 1817 r., Ustanowienie Dyrekcji Jeneralnej towarzystwa ogniowego przy Komisji Rządowej Spraw Wewnętrznych i Policji, D.P.K.P., t. III, s. 59.

${ }^{14}$ Postanowienie namiestnika z 28 stycznia 1817 r., Urządzenie i przepis względem zaprowadzenia towarzystwa ogniowego miast, D.P.K.P., t. III, s. 60 i n. 
być powszechny i wyłączny. Na mocy art. 17 wprowadzono zakaz przystępowania do zagranicznych towarzystw ogniowych pod karą 500 złotych. Dla wszystkich nieruchomości zabudowanych w miastach Królestwa Polskiego zostały sporządzone „taxy szczegółowe”, stosownie do wzoru ujętego w załączniku A. Znalazły się tam szczegółowe informacje o konstrukcji i stanie technicznym zabudowań. Czynniki te wpływały na ocenę zagrożenia pożarowego oraz wartość nieruchomości, przez co decydowały o wysokości składki. Prawodawca expressis verbis wskazał, że oszacowana wartość zabudowań nie mogła przekraczać wysokości szkody mogącej powstać podczas ewentualnego pożaru. Aby przeciwdziałać potencjalnym nadużyciom wyznaczono biegłych (,taxatorowie”), odpowiednio: w mniejszych miastach przez komisarzy obwodowych, w większych przez burmistrzów lub prezydentów, którzy, uwiarygodniając czynności złożeniem przysięgi, dokonywali oszacowania wartości zabudowań. Diety i koszty poniesione przez biegłych zatwierdzała właściwa komisja wojewódzka, a pokrywane były z funduszy miejskich (art. 4). Szacowanie wartości miało się odbywać w obecności właściciela oraz dwóch deputowanych miejskich albo burmistrza lub ławnika. „Taxy” miały być przygotowane $\mathrm{w}$ dwóch egzemplarzach i podpisane przez uczestników wyceny oraz zatwierdzone przez właściwego burmistrza lub prezydenta. W przypadku uchylania się właściciela od obowiązku sporządzenia wyceny lub powstania rozbieżności w zakresie wysokości oszacowanej wartości, stosowną informację uwzględniano w protokole. Wątpliwości w tym zakresie rozstrzygała Dyrekcja Generalna, która po weryfikacji decydowała o poprawności wyceny lub konieczności sprostowania uchybień. Oszacowaniu wartości przeprowadzonej przez „Budowniczego Rządowego” podlegały również budynki „Rządowe, Istytutowe i Gminne (...) także Kościoły i Klasztory" (art. 1). Nieruchomości te ubezpieczano na zasadach ogólnych z wyłączeniem nakładów zbytkowych, podnoszących prestiż obiektu, lecz nie wpływających na jego walory użytkowe. Składki uiszczano z funduszy władz lokalnych (art. 6).

Odrębnie potraktowano zabudowania sakralne i kultu religijnego. Decyzję w sprawie objęcia ich ochroną pozostawiono Komisji Rządowej Wyznań Religijnych i Oświecenia Publicznego (KRWRiOP). Ministerstwo rozstrzygało sprawę na wniosek właściwych komisji wojewódzkich. Natomiast objęcie ochroną obiektów kultu religijnego ufundowanych przez prywatnych darczyńców uzależniono od ich woli. W przypadku pożaru obiektu, który nie podlegał ochronie Towarzystwa Ogniowego, wprowadzono zakaz zbierania od parafian datków na odbudowę (art. 7).

Decyzja o objęciu systemem ochrony wiatraków, młynów wodnych, tartaków, papierni, foluszy i innych obiektów produkcyjnych, uzależniano od ich położenia w miastach. W przypadku oddalenia od innych zabudowań miejskich, właściciel decydował o tym, czy przystąpi do systemu. Jednak jeżeli obiekty znajdowały się 
w bliskim sąsiedztwie innych zabudowań, przystąpienie do Towarzystwa Ogniowego stawało się obligatoryjne (art. 8).

Nie podlegały ubezpieczeniu budynki będące w złym stanie technicznym lub których instalacje dymowe nie spełniały obowiązujących ówcześnie standardów. Takie budynki i budowle miały być niezwłocznie wyłączone z użytkowania i rozebrane albo zostać poddane niezbędnemu remontowi w celu objęciu ochroną Towarzystwa (art. 9).

W art. 2 określono zasady opisu nieruchomości, stanowiącego podstawę systemu „tax”. Każdą nieruchomość indywidualizowano poprzez nadanie odrębnego numeru. Ponadto wyodrębniono poszczególne budynki i budowle wchodzące w skład danej nieruchomości. W ramach każdego zabudowania wyszczególniano część środkową (,korpus”) oraz skrzydła z dokładnym opisem usytuowania. Wymiary wszystkich istotnych elementów składowych zabudowań podlegały obmiarowi w łokciach warszawskich ${ }^{15}$. Przemnożone przez stawkę bazową opłaty w danej klasie wyznaczały sumaryczną wysokość składki uiszczanej od poszczególnych nieruchomości (art. 2). Właścicielom zabudowań, których wartość nie przekraczała 1200 złotych, pozostawiano wybór w zakresie sporządzenia szczegółowej wyceny. Oświadczenie o ich wartości weryfikowali biegli (art. 5).

Decyzje w sprawie objęcia ochroną ogrodzeń i parkanów pozostawiono właścicielom. System nie obejmował ruchomości znajdujących się w zabudowaniach oraz nakładów zbytkowych. Wyjątek stanowiły kadzie, kotły i garnce znajdujące się w browarach i gorzelniach, a także mechanizmy młyńskie. Objęcie ich ochroną pozostawiano woli właścicieli. Wysokość składki za te urządzenia uzależniono od klasy, do której zabudowanie zostało zaliczone (art. 2 i 3 ).

Po przeprowadzeniu wyceny, nieruchomości miały zostać ujęte w katastrze przygotowanym przez burmistrzów lub prezydentów. Wykaz sporządzano w czterech egzemplarzach. Dołączano do nich zestawienia „tax”. Następnie przekazywano komisarzowi obwodowemu, który przesyłał komplet właściwej komisji wojewódzkiej. Po przeprowadzeniu weryfikacji zgodności ich treści ze stanem faktycznym, komisje wojewódzkie potwierdzały wiarygodność zebranych danych i przekazywały dokumentację Dyrekcji Generalnej (art. 10). Po sprawdzeniu dokumentów i potwierdzeniu poprawności danych, Dyrekcja pozostawiała jeden egzemplarz w swoim archiwum. Pozostałe miały znajdować się w aktach komisji wojewódzkiej, komisarza obwodowego oraz prezydenta lub burmistrza. Przedmiotowa dokumentacja służyła jako podstawa poboru składek oraz likwidacji skutków pożarów (art. 11). Na ich podstawie burmistrzowie i prezydenci wydawali właścicielom nieruchomości świadectwa potwierdzające objęcie nieruchomości ochroną Towarzystwa Ogniowego (art. 14).

\footnotetext{
${ }^{15}$ Łokieć warszawski (staropolski) wynosił 59,6 cm.
} 
Dla nieruchomości objętych systemem ochrony z okresu Księstwa Warszawskiego wycena była sporządzana wyłącznie, jeśli zaszły istotne zmiany. Pozostałe zabudowania ubezpieczano na dotychczasowych warunkach, przy czym systematyka opisu powinna była odpowiadać nowym wzorom „tax” i katastru (art. 12). $\mathrm{Na}$ przeprowadzenie czynności wynikających z postanowienia wyznaczono sześciotygodniowy termin w przypadku obowiązujących dotychczas katastrów. Natomiast sporządzenie dokumentacji dla nieruchomości nieobjętych wcześniej ochroną prawodawca przewidywał okres trzymiesięczny. Naruszenie terminu skutkowało wydelegowaniem komisarzy na koszt urzędników zobowiązanych do przeprowadzenia stosownych czynności (art. 13).

Budynki nowo wybudowane, których wartość przekraczała 600 złotych, były zgłaszane Dyrekcji Generalnej w terminie sześciu tygodni pod rygorem grzywny 30 złotych za każdy rok opóźnienia. Zobowiązani do jej zapłacenia byli solidarnie burmistrz lub prezydent oraz właściciel nieruchomości (art. 15). Wszelkie inne modyfikacje wprowadzano w katastrach z końcem roku kalendarzowego. W tym celu na właścicieli nałożono obowiązek zgłoszenia burmistrzowi lub prezydentowi miasta zmian w terminie umożliwiającym przekazanie informacji Dyrekcji Generalnej przed 31 października (art. 16).

Tytuł II postanowienia regulował zasady poboru danin. Rozpoczęcie zbierania składek stałych następowało po zatwierdzeniu budżetu (,etatu”) rocznego przez KRSWiP (art. 18). Na podstawie etatów poborcy dokonywali zbiórki dwa razy w roku wraz z podatkiem od nieruchomości. Potwierdzenie spełnienia świadczenia następowało poprzez stosowny wpis do książeczek opłat, posiadanych przez właściciela nieruchomości, wydrukowanych na koszt Towarzystwa (art. 20).

Zebrane składki miały trafiać do kas obwodowych, a stamtąd do kas wojewódzkich. Niespełnione świadczenia były egzekwowane w trybie egzekucji skarbowej (art. 21-22). Środki ze składek ubezpieczeniowych gromadzono odrębnie od innych funduszy, którymi dysponowali komisarze obwodowi i komisje wojewódzkie (art. 24) Kasy wojewódzkie były zobowiązane do systematycznego przedkładania sprawozdań o stanie pobranych składek. Komisje wojewódzkie zostały ponadto zobowiązane do przekazywania środków Dyrekcji Generalnej (art. 23). Z kolei Dyrekcja Generalna została zobowiązana do przedkładania KRSWiP kwartalnych raportów o stanie środków Towarzystwa Ogniowego (art. 26). Ponadto z końcem roku składano dodatkową informację o zaległościach składkowych i niedoborach środków. Odpowiedzialnymi za stan finansów systemu byli w zakresie swojego władztwa odpowiednio: burmistrzowie i prezydenci miast, komisarze obwodowi, nadzorujący system radcy komisji wojewódzkich oraz komisarz administracji wewnętrznej Dyrekcji Generalnej (art. 28). Nadzór nad prawidłowym wykonywaniem obowiązków przez urzędników sprawowali ich przełożeni, dysponujący uprawnieniem do nakładania kar dyscyplinarnych na 
podwładnych (art. 29). Odmienne rozwiązanie wprowadzone w Warszawie, gdzie pobór składek prowadzili poborcy pod nadzorem prezydenta (art. 30).

Tytuł III postanowienia regulował procedurę wypłaty odszkodowania oraz odbudowy budynków lub budowli, które ucierpiały w pożarze. W ciągu 24 godzin po zakończeniu akcji ratowniczej burmistrz lub prezydent miasta albo umocowany przez nich urzędnik w asyście dwóch właścicieli nieruchomości położonych w mieście, udawał się na miejsce pożaru, gdzie przeprowadzał oględziny oraz sporządzał z tej czynności protokół. W celu oszacowania strat mógł skorzystać z pomocy biegłych. Budynki lub budowle opisywano oddzielnie, stosownie do podziału znajdującego się w katastrze. Ponadto w dokumentacji uwzględniano wynagrodzenie przysługujące za sprzęt użyty do gaszenia pożaru (art. 33). Protokół sporządzano w trzech egzemplarzach. Dokumentację uwierzytelniono podpisami wszystkich uczestników, w tym poszkodowanego właściciela (art. 31). Urzędnicy i właściciele nieruchomości uczestniczyli w czynnościach nieodpłatnie. Biegłym przysługiwało wynagrodzenie od 3 do 5 złotych, w zależności od wielkości miasta (art. 32).

Sprawozdanie z wizji lokalnej zawierającej wycenę strat i kosztów odbudowy burmistrz przesyłał w terminie czternastu dni komisarzowi obwodowemu, który w tym samym terminie przekazywał dokumentację komisji wojewódzkiej. Ta z kolei w analogicznym terminie po weryfikacji zgodności ze stanem faktycznym, przekazywała materiały Dyrekcji Generalnej. Po zatwierdzeniu tych działań i zachowaniu jednego egzemplarza, Dyrekcja zwracała dokumentację komisji wojewódzkiej, a następnie wypłacała środki poszkodowanemu. Właściwe wydatkowanie środków na odbudowę zniszczonych zabudowań nadzorowała komisja wojewódzka (art. 36).

W miastach liczących mniej niż dwieście zabudowań, burmistrz w ciągu 24 godzin informował o pożarze komisarza obwodowego, który dokonywał wizji lokalnej osobiście lub za pośrednictwem wyznaczonego pełnomocnika (art. 34). Także w przypadku pożaru obejmującego znaczniejszą część miasta burmistrz nie mógł samodzielnie dokonać wizji. Kompetencja ta przysługiwała komisarzowi obwodowemu. Ten w asyście „budowniczego przysięgłego” sporządzał wymaganą dokumentację. Ponadto asystujący biegły był zobowiązany do opracowania planu odbudowy zniszczonych zabudowań (art. 35). Egzemplarz tej dokumentacji trafiał do KRSWiP (art. 36 in fine).

Zaświadczenia („kwity”) pogorzelców uprawniające do wypłaty świadczenia potwierdzał komisarz obwodowy, a następnie były przekazywane Dyrekcji Głównej za pośrednictwem komisji wojewódzkiej (art. 37). Wypłata następowała w trzech równych ratach. Środki były wolne od egzekucji sądowej (art. 46). Prawodawca nakazywał, aby odbudowa była prowadzona bez zbędnej zwłoki, a środki wypłacane przez Towarzystwo Ogniowe przeznaczano wyłącznie na ten cel. Wartość odtworzonych zabudowań nie mogła być niższa niż ujawniona w ka- 
tastrze. Wprowadzano wymóg, aby wszystkie budynki mieszkalne były wznoszone na murowanych fundamentach i miały murowane kominy (art. 43). W terminie sześciu tygodni od zakończenia procesu budowlanego inwestor miał obowiązek przekazania Dyrekcji Generalnej świadectwa odbudowy. Jeżeli deklarowana wartość nowych zabudowań przekraczała trzy tysiące złotych, weryfikację świadectwa przeprowadzał biegły (art. 45).

Nadzór nad poprawnością przekazywania środków sprawowały komisje wojewódzkie pod groźbą odpowiedzialności dyscyplinarnej jej członków (art. 38). Procedura wypłaty środków miała zakończyć się w terminie dwóch miesięcy od pożaru. Osoba odpowiedzialna za przekroczenie tego terminu była zobowiązana do pokrycia strat spowodowanych opóźnieniem (art. 39). Brak zgłoszenia Dyrekcji Generalnej pożaru w terminie czterech miesięcy od zdarzenia skutkował utratą uprawnienia poszkodowanych do uzyskania świadczenia. Aby uniknąć negatywnych konsekwencji, właściciel nieruchomości mógł przed upływem tego terminu zgłosić roszczenie Dyrekcji Generalnej z pominięciem zwykłej ścieżki proceduralnej (art. 40). Organ ten był zobowiązany do przedłożenia KRSWiP kwartalnych sprawozdań zawierających informację o wypłaconych świadczeniach (art. 47).

$\mathrm{W}$ art. 42 przewidziano wynagrodzenie za podstawienie w przeciągu pół godziny od wybuchu pożaru sprzętu gaśniczego (,sikawek”). Stawki były uzależnione od ilości i rodzaju dostarczonego sprzętu. Konieczne było jednak uzyskanie świadectwa miejscowych władz, potwierdzających jego wykorzystanie w akcji gaśniczej (art. 42). Z funduszy Towarzystwa pokrywano również straty w sprzęcie gaśniczym, które powstały podczas gaszenia pożaru. Zakup nowego sprzętu należał do władz miejskich (art. 43).

Tytuł VI postanowienia został poświęcony rachunkowości Towarzystwa Ogniowego. Do prowadzenia dokumentacji finansowej miały zastosowanie przepisy ogólne obowiązujące instytucje publiczne Królestwa Polskiego. Budżet roczny Towarzystwa miał być przygotowany przez Dyrekcję Generalną, stosownie do wzoru zamieszczonego w załączniku $\mathrm{G}$ do postanowienia (art. 48). Z uwagi na to, że nieruchomości zabudowane były dzielone na dwie klasy, w ramach których następował pobór składek i wsparcie finansowe, także sprawozdawczość finansowa była prowadzona podług tego samego schematu (art. 49). Sprawozdanie zawierało informacje z podziałem na przychody i rozchody Towarzystwa. Nadzór nad realizacją obowiązków wynikających z postanowienia namiestnik powierzał komisjom rządowym, zgodnie z kompetencjami (art. 50).

Z raportu przedłożonego w 1818 r. Sejmowi przez Radę Stanu wynikało, że proces wdrażania nowych rozwiązań początkowo postępował powoli ${ }^{16}$. Rozwiązanie polegające na objęciu nieruchomości zabudowanych systemową ochroną

${ }^{16}$ Art. 73 ustawy konstytucyjnej Królestwa Polskiego z 27 listopada 1815 r., D.P.K.P., t. I., s. 42. 
przed skutkami pożarów Izba Poselska oceniła jednak bardzo pozytywnie ${ }^{17}$. Sytuacja poprawiała się stopniowo, o czym świadczy kolejny raport Rady Stanu przedstawiony podczas Sejmu w $1820 \mathrm{r}$. Nadal jednak poważnym problemem było zadłużenie Towarzystwa Ogniowego z tytułu wypłaty zaległych świadczeń za okres 1806-1816, wynoszących 2802438 złotych $^{18}$. Na konieczność jego rozwiązania wskazywała Izba Poselska oraz Senat ${ }^{19}$.

\section{TOWARZYSTWO OGNIOWE WSI}

W postanowieniu z 25 lutego 1817 r. namiestnik określił zasady organizacji i funkcjonowania Towarzystwa Ogniowego dla wsi. Stosowny projekt przedłożyła KRSWiP. Tytuł I zawierał przepisy ogólne. System ochrony objął wszystkie zabudowane nieruchomości: w dobrach narodowych, instytucji, duchowieństwa oraz prywatnych osób prawnych i fizycznych (art. 1). Komisje rządowe zgodnie z właściwością miały obowiązek przygotowania list dóbr podlegających ubezpieczeniu, a następnie przekazania ich Dyrekcji Generalnej Towarzystwa Ogniowego (art. 2).

Właściciele prywatnych dóbr dziedzicznych, o ile przystąpili do Towarzystwa Ogniowego, ubezpieczali budynki i budowle według samodzielnie oszacowanej wartości, pod warunkiem, że nie przekraczała ona znacznie wartości rzeczywistej (art. 5). Dysponowali przy tym uprawnieniem do wystąpienia z końcem roku $\mathrm{z}$ Towarzystwa, co powodowało $\mathrm{w}$ ich przypadku nieobowiązkowe uczestnictwo w systemie (art. 3). Jednocześnie dysponowali roszczeniem wobec włościan zamieszkujących ich dobra i zobowiązanych do utrzymania zabudowań, aby ci we własnym zakresie przystępowali do Towarzystwa Ogniowego. Określali wtedy wartość zabudowań, od której szacowano wysokość składki (art. 4 i 5).

W przypadku kościołów (art. 7) oraz ruchomości (art. 8) prawodawca odsyłał do postanowienia o Towarzystwie Ogniowym miast. Zabudowania parafialne oraz szkolne podlegały ochronie. Składki były uiszczane odpowiednio przez: proboszcza oraz z funduszu, z którego utrzymywano szkołę (art. 9).

Tytuł II postanowienia został poświęcony zasadom przygotowania „tax” i katastru. Zabudowania wiejskie podlegały umieszczeniu w zestawieniu sporzą-

17 Uwagi Sejmu Królestwa Polskiego o Raporcie Rady Stanu z działalności rządu i stanu kraju w latach 1816-1817 [w:] J. Leskiewiczowa, F. Ramotowska (oprac.), Sejm Królestwa Polskiego o działalności rządu i stanie kraju 1816-1830, Warszawa 1995, s. 35.

18 Raport Rady Stanu Królestwa Polskiego z działalności rzadu i stanu kraju $w$ latach 1816-1817 przedstawiony na posiedzeniu Sejmu dnia 28 marca 1818 r., Raport Rady Stanu Królestwa Polskiego z działalności rządu i stanu kraju w latach 1818-1819 przedstawiony na posiedzeniu Sejmu dnia 14 września 1820 r. [w:] J. Leskiewiczowa, F. Ramotowska (oprac.), Obraz Królestwa Polskiego w okresie konstytucyjnym, Warszawa 1984, s. 56, 130-131.

19 Uwagi Sejmu Królestwa Polskiego o Raporcie Rady Stanu z działalności rządu i stanu kraju w latach 1818-1819 [w:] Sejm Królestwa ..., s. 86-87, 168-169. 
dzonym w trzech egzemplarzach, zgodnie z wzorem ujętym w Załączniku A do postanowienia. Do najważniejszych informacji należało wskazanie aktualnego posiadacza zabudowań oraz ich dokładny wykaz wraz z określeniem wymiarów i przeznaczenia poszczególnych budynków i budowli (art. 9).

Przygotowane według powyższego wzoru dane właściciel dóbr miał obowiązek przekazać komisarzowi obwodowemu, który weryfikował oszacowaną wartość, a następnie przesyłał dokumentację Dyrekcji Generalnej za pośrednictwem komisji wojewódzkiej. Ta z kolei weryfikując wartość mogła zadecydować o powtórnym sprawdzeniu rzetelności deklaracji właściciela (art. 10 i 11). Po weryfikacji Dyrekcja Generalna zatwierdzała „taxy” i katastry, pozostawiając jeden egzemplarz w aktach. Dwa pozostałe podlegały zwrotowi komisarzowi obwodowemu. Jeden egzemplarz zatrzymywał, a drugi wydawał właścicielowi. Dokument ten stanowił jednocześnie świadectwo objęcia ochroną nieruchomości (art. 12).

Zatwierdzone według powyższego schematu ,taxy” Dyrekcja Generalna ewidencjonowała w katastrze obwodowym, stanowiącym część składową katastru głównego. Zestawienie to stanowiło podstawę poboru składek oraz wypłaty środków dla właścicieli nieruchomości poszkodowanych w pożarze (art. 14).

Zmiana wysokości składek następowała z końcem roku kalendarzowego. Zainteresowani właściciele zgłaszali wniosek właściwemu komisarzowi obwodowemu przed końcem października danego roku. Był to również termin końcowy zgłoszenia decyzji o wystąpieniu z Towarzystwa. W kwestii przynależności do zagranicznych towarzystw ubezpieczeniowych prawodawca odsyłał do postanowienia o Towarzystwach Ogniowych dla miast (art. 15). W Tytule III uregulowano zasady poboru składek. Składki dzielono na stałe i dodatkowe. Wysokość pierwszej z nich określono na poziomie 8 groszy od 100 zł wartości zabudowań. Regulowana była w dwóch półrocznych ratach (art. 16). Właściciele gorzelni, browarów, mydlarni, farbiarni, kuźni i zakładów produkcyjnych wymagających użycia otwartego ognia, wnosili opłaty w podwójnej wysokości (art. 17). Pobór składki dodatkowej odbywać się miał na wniosek KRSWiP w sytuacjach uzasadniających jej zwiększenie. Natomiast w przypadku nadwyżki środków, składki w roku następnym ulegały proporcjonalnemu obniżeniu (art. 19).

Płatnikami składek byli właściciele, dzierżawcy lub inne osoby mające tytuł prawny do nieruchomości. Egzekucja nieuiszczonych należności była prowadzona $z$ ich majątku. Podmioty te dysponowały uprawnieniami do poboru równowartości składek od osób faktycznie korzystających z zabudowań w majątku, takich jak: ludność folwarczna, osadnicy i czynszownicy (art. 20). Z kolei w dobrach dziedzicznych wójt lub jego zastępca uiszczał składkę z kasy gminnej. Egzekucję zaległych świadczeń prowadzono wyłącznie z majątku wójta (art. 21).

Dyrekcja Generalna miała obowiązek przygotować budżet roczny Towarzystwa, najpóźniej do 31 grudnia roku poprzedniego. Jako wzór budżetu służył ana- 
logiczny dokument Towarzystwa Ogniowego dla miast. Po zatwierdzeniu przez KRSWiP, budżet miał być ogłaszany drukiem (art. 18). Obowiązywał zakaz łączenia zgromadzonych środków z budżetem dla miast (art. 23).

Prawodawca przewidywał obowiązkową rezerwę w kasie Towarzystwa w wysokości 100 tysięcy złotych. Dzięki temu świadczenia na rzecz pogorzelców miały być wypłacane najpóźniej w terminie trzech miesięcy od pożaru. Rezerwa miała pochodzić z oszczędności uzyskanej podczas wykorzystania środków ze składek stałych lub ze zbiórki składek dodatkowych (art. 22).

Tytuł IV postanowienia został poświęcony zasadom wypłaty świadczeń oraz odbudowy spalonych zabudowań. W ciągu 24 godzin od ugaszenia pożaru poszkodowani mieli powiadomić lokalne władze, które były zobowiązane przekazać tę informację komisarzowi obwodowemu, szczegółowo opisując zniszczone zabudowania (art. 24). W ciągu trzech dni komisarz obwodowy lub wyznaczony przez niego pełnomocnik miał przeprowadzić wizję lokalną, z której sporządzano stosowny protokół w trzech egzemplarzach. Czynnościom tym mieli asystować dwaj właściciele lub osadnicy. Biegli uczestniczyli w czynnościach wyjątkowo, o ile część materiałów budowalnych nadawała się do powtórnego użycia lub gdy strat nie można było oszacować w inny sposób. Protokół podpisywał komisarz, asystujący właściciel, poszkodowany i biegli (art. 25). Dokumentację przekazywano Dyrekcji Generalnej za pośrednictwem komisji wojewódzkich. Po przeprowadzeniu weryfikacji i zatwierdzeniu, dwa $\mathrm{z}$ trzech egzemplarzy podlegały zwrotowi władzom lokalnym (art. 26).

Wypłata środków na rzecz poszkodowanych następowała w co najmniej dwóch ratach. Potwierdzenie ich wykonania komisarz obwodowy przekazywał Dyrekcji Generalnej (art. 27). Zatwierdzona wypłata nie mogła być wstrzymana, niezależnie od ustalonych przyczyn pożaru. Prawodawca podkreślił, że przepis ten nie kolidował z regulacjami określającymi zasady odpowiedzialności sprawców podpaleń (art. 28). Zasadą było, że wypłata następowała do rąk właścicieli dóbr, będących płatnikami składek. Osadnicy, czynszownicy lub członkowie innych grup ludności wiejskiej, opłacający składkę, mogli ubiegać się o wypłatę świadczenia bezpośrednio na ich rzecz, o ile uprawdopodobnili zamiar odbudowy zniszczonych zabudowań (art. 29). W pozostałym zakresie prawodawca odsyłał do art. 39-47 postanowienia o Towarzystwie Ogniowym miast (art. 30-31).

\section{ZMIANY W SYSTEMIE ZABEZPIECZENIA PRZECIWPOŻAROWEGO}

Obowiązki wynikające z przepisów art. 45 postanowienia z 28 stycznia 1817 r. i art. 30 postanowienia z 25 lutego 1817 r. w zakresie obligatoryjnego uczestnictwa biegłego w zakresie budownictwa okazały się trudne do zrealizowa- 
nia. Dlatego 25 lipca 1818 r. namiestnik wydał postanowienie ${ }^{20}$, na mocy którego obowiązek ten został utrzymany wyłącznie wobec nieruchomości położonych w miastach wojewódzkich (art. 1 i 3). W innych miastach i na terenach wiejskich opinia biegłego była wymagana, o ile wartość wzniesionych zabudowań przekraczała $12.000 \mathrm{zł}$. W pozostałych przypadkach szacowania wartości dokonywali: burmistrz lub prezydent wraz z dwiema osobami uznawanymi za specjalistów w dziedzinie budownictwa. Każdorazowo sporządzona dokumentacja była zatwierdzana przez komisarza obwodowego (art. 2) ${ }^{21}$.

O ile system ochrony przed skutkami pożarów obiektów miejskich systematycznie ulegał poprawie, dzięki czemu została wygospodarowana nadwyżka środków, Towarzystwo Ogniowe dla wsi przez cały okres raportowania pozostawało deficytowe. W raporcie przedłożonym Sejmowi w 1825 r. wskazano, że sytuacja nie ulegnie poprawie dopóki nie zostaną zaostrzone sankcje karne za podpalenia co, zdaniem Rady Stanu, miało przyczynić się do zwiększenia skuteczności prewencji ogólnej22. Stanowisko spotkało się ze zrozumieniem, bowiem obie izby przychyliły się do poglądu o konieczności znowelizowania Kodeksu karzącego. Ponadto Izba Poselska przedstawiła katalog innych propozycji zmierzających do usprawnienia istniejącego systemu ${ }^{23}$.

\section{PREWENCYJNE DZIAŁANIA PRZECIWPOŻAROWE}

Obok organizacji Towarzystw Ogniowych, władze Królestwa Polskiego zadbały również o zabezpieczenie stanu technicznego instalacji dymowych oraz materiałów i sprzętu niezbędnego do gaszenia ognia. W tym celu na wniosek KRSWiP namiestnik Zajączek wydał 15 czerwca 1819 r. stosowne postanowie-

${ }^{20}$ Postanowienie namiestnika z 25 lipca 1818 r. o zwolnieniu przepisów względem sporządzenia wywodów słownych rewizyjnych z budowli które restaurowane zostały przez osoby do składki towarzystwa ogniowego należące, D.P.K.P. t. VI, s. 220.

${ }^{21} \mathrm{~W}$ kolejnych latach również podnosiły się głosy o konieczności zmian w systemie ochrony przed skutkami pożarów. Na skutek petycji Izby Poselskiej Aleksander I polecił przygotować w 1826 r. projekt aktu prawnego reorganizującego Towarzystwo Ogniowe. Polecenie to nie zostało jednak wykonane. Raport Rady Stanu Królestwa Polskiego z działalności rządu i stanu kraju w latach 1824-1828 przedstawiony na posiedzeniu Sejmu dnia 29 maja 1830 r. [w:] Obraz Królestwa..., s. 291.

${ }^{22}$ Raport Rady Stanu Królestwa Polskiego z działalności rządu i stanu kraju $w$ latach 1820-1823, przedstawiony na posiedzeniu Sejmu dnia 14 maja 1825 r. [w:] Obraz Królestwa..., s. 216-217. Ostatecznie Sejm Królestwa Polskiego z 1825 r. wprowadził nowelizację Kodeksu karzącego Królestwa Polskiego zaostrzającą sankcje za podpalenia. Zob. Zmiany Kodeksu Kryminalnego Księgi I i II o podpaleniu, D.P.K.P., t. IX, s. 345-351.

${ }^{23}$ Uwagi Sejmu Królestwa Polskiego o Raporcie Rady Stanu z działalności rządu i stanu kraju w latach 1820-1823 [w:] Sejm Królestwa..., s. 208-209, 254. 
nie ${ }^{24}$. W każdym mieście miał zostać zatrudniony kominiarz przeprowadzający okresowe kontrole stanu kominów we wszystkich budynkach. W miastach większych oraz organizujących handel kontrola odbywać się miała raz w miesiącu, natomiast w miasteczkach rolniczych co najmniej raz na kwartał (art. 1). Kominiarz ponosił odpowiedzialność za ewentualne skutki niedbalstwa podczas przeprowadzania kontroli. Po przeprowadzeniu czynności kontrolnych był zobowiązany do przedłożenia burmistrzowi ustnego raportu z przeprowadzonych czynności oraz wskazania zakresu koniecznych napraw. Na podstawie tych informacji burmistrz sporządzał protokół, podług którego realizowano wymagane prace remontowe. Dozorca miast został zobowiązany do bieżącej kontroli wykonania przedmiotowych prac (art. 2).

W postanowieniu określono wymagania techniczne i sprzętowe nałożone na miasta w związku z organizacją systemu ochrony przeciwpożarowej ${ }^{25}$. Każdy dom powinien mieć przygotowany dostęp do kominów od strony dachu oraz węborek drewniany. $Z$ kolei na dziesięć sąsiadujących domów przypadał obowiązek zakupu dwóch bosaków, kubła, sikawki ręcznej oraz beczki do transportu wody (art. 3).

W miastach liczących między sto a sto pięćdziesiąt domów mieszkalnych należało utrzymywać w gotowości jedną sikawkę, która odpowiadałaby zasięgiem najwyższym budynkom. Do obowiązkowego sprzętu gaśniczego zaliczono również cztery stągwie do gromadzenia wody. W miastach liczących do trzystu budynków mieszkalnych liczba sprzętu miała zostać podwojona. $Z$ kolei w większych miastach na każde kolejne dwieście domów przypadać powinna wielokrotność wymaganego sprzętu (art. 7). Wykonanie postanowienia przekazano KRSWiP. Dzień ogłoszenia postanowienia ustalono na 20 lipca $1819 \mathrm{r}^{26}$

Inną prawnie uregulowaną kwestią, mającą znaczenie dla włościan dotkniętych pożarem, było zwolnienie na mocy postanowienia namiestnika z 23 marca 1823 r. prowadzonej przez nich korespondencji związanej ze zgłoszeniem zdarzenia oraz wypłatą środków z obowiązku wykorzystania papieru stemplowego. Pozostała korespondencja, zarówno prowadzona przez innych poszkodowanych właścicieli, jak również wynikająca z bieżącej działalności Towarzystwa Ogniowego, podlegała opłacie stemplowej w wysokości 2 złotych $^{27}$.

${ }^{24}$ Postanowienie namiestnika z 15 czerwca 1819 r., zaprowadzenie narzędzi do gaszenia ognia po miastach, D.P.K.P., t. VI, s. 335.

${ }^{25}$ Była to zmiana stanowiska władz Królestwa Polskiego w tym zakresie, bowiem 14 czerwca 1819 r. Zgromadzenie Ogólne Rady Stanu uznało, że kwestie związane z określeniem obowiązku gromadzenia sprzętu gaśniczego należą do zagadnień administracyjnych i nie wymagają wydania postanowienia namiestnika. Rps., AGAD, I Rada Stanu Królestwa Polskiego, sygn. 271 Towarzystwo Ogniowe, s. 60-63.

${ }^{26}$ D.P.K.P., t. VI, s. 341.

27 Postanowienie namiestnika z 25 marca 1823 r., Uwolnienie włościan od używania papieru stemplowego $w$ korespondency(a)ch dotyczacych się doznanego pożaru i oznaczenie jakie inne przedmioty tego rodzaju ulegaja optacie stempla, D.P.K.P., t. VIII, s. 60. 


\section{UWAGI KOŃCOWE}

Wśród badaczy panuje powszechna zgoda w kwestii dopuszczalności wykorzystania wszelkich dostępnych źródeł, pozwalających zrekonstruować wybrane przejawy myśli polityczno-prawnej ${ }^{28}$. W przypadku odtworzenia wizji politycznej rządzących, szczególnie przydatna staje się analiza porządku prawnego, będącego narzędziem do jej urzeczywistnienia. Także w przypadku Królestwa Polskiego doby konstytucyjnej analiza rozwiązań prawnych dotyczących organizacji i funkcjonowania systemu ochrony przeciw skutkom pożarów pozwala naświetlić koncepcję polityki wewnętrznej ówcześnie rządzących państwem.

$\mathrm{Na}$ uwagę zasługuje powszechność przyjętego rozwiązania. Spełniało ono rolę powszechnego ubezpieczenia społecznego od negatywnych następstw żywiołu szczególnie niebezpiecznego na ówczesnym etapie rozwoju społeczno-gospodarczego. Obligatoryjne co do zasady uczestnictwo w systemie ochrony sugeruje także, iż pomimo realnego zagrożenia właściciele nieruchomości zabudowanych starali się unikać dodatkowych obciążeń finansowych. Wykazywali przy tym znaczną skłonność do ryzyka lub nie potrafili ocenić prawdopodobieństwa zagrożenia pożarowego. Dlatego prawodawca nie pozostawił zainteresowanym swobodnego wyboru. Inną sprawą jest to, że rządzący zdawali sobie zapewne sprawę, iż skuteczność tego rodzaju rozwiązań wymagała powszechności zastosowania.

Władze Królestwa Polskiego dążyły do zbudowania sprawnego systemu ochrony przed pożarami. Jest to wyraźnie widoczne w przyjętej formie ewidencji nieruchomości i poboru składek, jak również w procedurze szacowania strat oraz wypłaty odszkodowania przeznaczonego na odbudowę zniszczonych nieruchomości. Zasady funkcjonowania Towarzystwa Ogniowego miały też na celu przeciwdziałanie wyłudzeniom świadczeń. Wysoki poziom formalizacji skutkował jednak znacznym zbiurokratyzowaniem systemu. Wzrosła w konsekwencji rola aparatu administracyjnego państwa, w szczególności administracji terenowej, bez której skutecznego i efektywnego działania przepisy materialnoprawne nie byłyby skutecznie realizowane w praktyce.

Wprowadzone rozwiązania świadczą również o umiejętności holistycznego spojrzenia rządzących na kwestie porządku i bezpieczeństwa wewnętrznego. Treść przyjętych regulacji prawnych wskazuje, że władze miały świadomość negatywnych konsekwencji pożarów, nie tylko w wymiarze indywidualnej egzystencji, ale również niekorzystnych skutków takich zdarzeń dla porządku społeczno-gospodarczego w kraju. Stąd zapewne duży nacisk na działania prewencyjne. Na pod-

${ }^{28}$ K. Grzybowski, Z zagadnień metodologii historii doktryn politycznych, „Czasopismo Prawno-Historyczne”, 1956, t. VIII, s. 1, s. 297 i n.; M. Jaskólski (red.), Słownik historii doktryn politycznych, Warszawa 1999, t. 2, s. 412-413; 
stawie przeprowadzonej analizy podstaw prawnych skomplikowanego systemu uzasadniony jest pogląd o osiągnięciu przez władze Królestwa Polskiego okresu przedpowstaniowego znaczącego poziomu umiejętności organizatorskich ${ }^{29}$.

Należy zauważyć, iż rozwiązania w zakresie ochrony przeciwpożarowej zyskały akceptację opinii publicznej. Świadczy o tym treść uwag wniesionych przez obie izby sejmowe w 1830 r., dokonujące oceny na podstawie kilkunastoletnich doświadczeń praktycznych. Izba Poselska uznała, że działalność Towarzystwa Ogniowego, a w szczególności Dyrekcji Generalnej, należy uznać za wzorową. Opinię tę potwierdza stanowisko Senatu, który zaproponował, aby analogiczne rozwiązania wprowadzić również do polityki prewencyjnej rządu w zakresie ochrony przed innymi klęskami żywiołowymi ${ }^{30}$.

\title{
LEGAL BASES OF THE FIRE PROTECTION SYSTEM IN THE KINGDOM OF POLAND (1815-1830)
}

\begin{abstract}
Fire was considered to be one of the most dangerous natural elements for mankind in the past. Conflagrations not only constituted a direct threat to life and health. They also resulted in the destruction of material resources as well as imperilled the existence of its victims. Moreover, fires carried negative consequences for the whole socio-economic system. The purpose of this article is to present the domestic policy of the authorities concerning the issue of fire protection in the Kingdom of Poland on the basis of the contemporary legal regulations.
\end{abstract}

\section{BASE LEGALE DU SYSTEME DE PROTECTION CONTRE L'INCENDIE AU ROYAUME DE POLOGNE (1815-1830)}

\section{Resumé}

Dans le passé, le feu était l'un des éléments naturels qui menaçaient particulièrement l'homme. Les incendies n'étaient pas seulement une menace directe pour la vie et la santé. En provoquant la destruction de biens matériels, ils menaçaient également l'existence biologique des victimes. Ils ont également causé des conséquences négatives pour l'ensemble du système socio-économique. L'objectif de cette étude est de présenter les fondements de la politique interne des autorités du Royaume de Pologne (1815-1830) dans le domaine de la protection contre l'incendie sur base de la législation applicable à l'époque concernée.

${ }^{29}$ Aktywność działaczy publicznych doby konstytucyjnej Królestwa Polskiego nakazuje poszukiwanie w tym okresie zalążków zarządzania publicznego na ziemiach polskich. Zob.: R. Kania, Usprawnić państwo. Myśl społeczno-polityczna Rajmunda Rembielińskiego, Płock 2015.

${ }^{30}$ Uwagi Sejmu Królestwa Polskiego o Raporcie Rady Stanu z działalności rządu i stanu kraju w latach 1824-1830 [w:] Sejm Królestwa ..., s. 309-311, 409-410. 